Membumikan Iklim Pendidikan Multikultural Dalam Mencegah....

\title{
MEMBUMIKAN IKLIM PENDIDIKAN MULTIKULTURAL DA- LAM MENCEGAH SIKAP EKSTRIMISME BERAGAMA DI SD SINTHA JEMBER ${ }^{1}$
}

\author{
Leny Marinda \\ LPPK Sakinah DPD BKPRMI Jember \\ Pascasarjana IAIN Jember \\ lenymarindasip@gmail.com
}

\begin{abstract}
ABSTRAK:
Indonesia sebagai Negara yang oleh Cliffort Geertz disebut sebagai new state of old societies. Indonesia adalah Negara baru yang terbentuk dari komunitaskomunitas lama berupa kerajaan, komunitas budaya, kelompok suku, agama dan sebagainya. Karena itu, Indonesia sering disebut sebagai bangsa yang majemuk (plura). Pendidikan multikultural, sebagai salah satu alternatif pendekatan pembelajaran, menjadi salah satu ikhtiar lembaga pendidikan dalam menanamkan nilai-nilai toleransi antar umat beragama. Usia anak SD yang tergolong usia operasi konkrit yang perlu dibimbing dalam menterjemahkan konsep abstrak ke dalam konsep konkrit. Dengan membiasakan anak berinteraksi di tengah perbedaan dan keberagaman, ketika mendapatkan bimbingan yang tepat anak dapat memahami dan bijak menyikapi perbedaan tersebut. hal ini sejalan dengan semangat yang ditampilkan kurikulum 2013 dengan pembelajaran "bermakna" nya. Penelitian ini menggunakan pendekatan penelitian kualitatif-deskriptif. Penelitian ini menggambarkan bagaimana pembelajaran multikultural yang dilaksanakan di SD Sintha dilaksanakan. Pengumpulan data dalam penelitian ini menggunakan teknik observasi, wawancara dan dokumentasi untuk mengungkap fakta di lokasi penelitian. Penelitian ini diharapkan mampu memberikan kontribusi dalam menggambarkan sikap menghargai perbedaan yang harus ditanamkan kepada siswa serta menghindari sikap ekstrimisme dalam beragama di kalangan peserta didik.
\end{abstract}

Kata Kunci: Iklim Pendidikan Multicultural, Sikap Ekstrimisme Beragama

\footnotetext{
${ }^{1}$ Saripati tulisan ini pernah dipresentasikan di forum ISOLEC (International Seminar Of Language, Education And Culture) yang di inisiasi oleh Fakultas Sastra Universitas Negeri Malang di hotel Aria Gajayana Malang 14-15 September 2019
}

80 | FENOMENA, Vol.19 No.1April 2020 


\section{Leny Marinda}

\section{ABSTRACT:}

Indonesia is a country that Cliffort Geertr. calls the new state of old societies. Indonesia is a new country formed from old communities in the form of kingdoms, cultural communities, ethnic groups, religions and so on. Therefore, Indonesia is often referred to as a pluralistic nation. Plurality and multiculturality possessed by the State of Indonesia in fact not only become wealth and identity, but also trigger endless religious, ethnic and cultural conflicts. Therefore it is important to formulate awareness of differences in Indonesian society, and it would be better if done early. Multicultural education, as an alternative approach to learning, has become one of the efforts of educational institutions in instaling the values of tolerance among religious communities. The age of elementary school children who are classified as the age of concrete operations that need to be guided in translating abstract concepts into concrete concepts. By getting children to interact amid differences and diversity, when getting the right guidance the child can understand and wisely respond to these differences. this is in line with the spirit displayed by the 2013 curriculum with its "meaningful" learning. This research uses a qualitative-descriptive research approach. This study illustrates how multicultural learning that is carried out at SD Sintha is carried out. Data collection in this study uses observation, interview and documentation techniques to uncover the facts at the research location. This research is expected to be able to contribute in describing the attitude of respecting differences that must be instilled in students and avoiding the attitude of extremism in religion among students

Key Words: Multicultural Education Climate, Religion Exstremism Attitude

\section{PENDAHULUAN}

Sejak jatuhnya orde baru pada tahun 1998 lalu, skala dan ruang lingkup kekerasan mengatasnamakan agama dan kelompok komunal tertentu terus meningkat. Hal ini sejalan dengan tumbuhnya demokrasi dan desentralisasi. Kekerasan kolektif ini jauh melampaui kekerasan yang bersifat ekonomi maupun bentrok dan konflik antara masayarakat dan pemerintah karena kebijakan politik tertentu. ${ }^{2}$ Konflik poso, penutupan oleh FPI terhadap bangunan sekolah Sang Timur yang digunakan untuk peribadatan umat katolik di Tangerang, ultimatum terhadap aktifitas pembelaan pluralism di Padang, penyerbuan perkampungan milik jemaat Ahmadiyah di

2 Ahmad Suaedi, dkk, Politisasi Agama Dan Konflik Komunal: Beberapa Isu Penting Di Indonesia, Jakarta: The Wahid Institute, 2007. 343

FENOMENA, Vol.19 No.1April 2020 | 81 
Lombok Barat dan penyegelan gereja di beberapa tempat lainnya menjadi sederet data kekerasan atas nama agama pasca Pemilu 2004 yang berhasil di publikasikan di Majalah Gatra no. XVI tahun XII- 4 Maret 2006.

Diskursus tentang multikulturalisme di Indonesia mulai mengemuka alurnya ketika Mukti Ali (Menteri Agama pada cabinet pembangunan II) merumuskan konsep besarnya, yaitu progam pembinaan kerukunan hidup beragama di Indonesia. Format itu dikembangkan dengan format trilogi kerukunan yaitu: pertama, kerukunan intern umat beragama, suatu upaya dialogis menyangkut aspek-aspek pemikiran keagamaan, gerakan, peran sosial, dan sebagainya dalam satu agama demi kepentingan agama tersebut dan demi kepentingan bangsa secara keseluruhan. Kedua, kerukunan antar umat beragama, yaitu suatu upaya dialogis antar kelompok agama yang berbeda (Islam, Kristen, katolik, Hindu, budha, dan agama lainnya dan aliran kepercayaan). Ketiga, kerukunan antar umat beragama dengan pemerintah, yaitu suatu upaya dialogis antara pemerintah dengan pemeluk agama dalam raangka meningkatkan peran agama dan umat beragama dalam pembangunan nasional. ${ }^{3}$

Arah trilogi kerukunan tersebut tidak lari dari berbagai fenomena interaksi umat beragama di Indonesia. Ketika kita cermati hari ini, sejak dibukanya era keterbukaan informasi yang ditandai dengan tumbangnya orde baru dan kemunculan era reformasi pada akhir tahun 1997 dan awal 1998, merebak berbagai isu-isu dan ketegangan yang terjadi dalam agama maupun antar agama di Indonesia. Seperti halnya munculnya banyak aliran yang terlahir dari buah pemikiran cendekiawan dalam negeri, maupun aliran import dari Negara lain. Belum lagi kasus penodaan agama, munculnya "nabi-nabi" baru, fenomena aliran sesat hingga stereotype yang dilayangkan antar golongan dalam satu agama. serta merebaknya aksi-aksi bela agama yang terkadang berujung anarkis dan berujung hilangnya nyawa.

Integrasi wacana multikultural ke dalam pendidikan di Indonesia perlu memperhatikan konteks ke-indonesiaan serta karakteristik dari setiap kasus yang terjadi. Dalam pendidikan multikultural, konsep Bhineka Tunggal Ika yang bermakna berbeda-beda tetap satu jua, memiliki posisi penting dalam membangun kesadaran kemajemukan yang ada di Indonesia. Indonesia

${ }^{3}$ Abd. Muis Thabrani, Pengantar Dan Dimensi-Dimensi Pendidikan, Jember: STAIN Press, 2013. 137

82 | FENOMENA, Vol.19 No.1April 2020 


\section{Leny Marinda}

dengan 17. 504 pulau, 1.331 kelompok suku ${ }^{4}, 652$ bahasa daerah $^{5}$, berbagai ras dan agama aliran kepercayaan ini.

Kabupaten Jember, merupakan salah satu Kabupaten diantara 38 Kabupaten - Kota di Jawa Timur. Kabupaten Jember, terletak disebelah timur Kabupaten Lumajang, sebelah barat Kabupaten Banyuwangi dan sebelah selatan Kabupaten Bondowoso. Kabupaten Jember, memiliki sedikitnya 31 Kecamatan, 22 kelurahan dan 245 desa. Dengan jumlah penduduk 2.451.081 jiwa, dan luas wilayah 3.092.34 KM2. ${ }^{6}$

Dari sisi latar belakang etnis atau ras, dapat dijumpai beberapa suku sebagai berikut; 1) suku Jawa, 2) suku Madura, 3) suku Arab, 4) suku China, 5) suku Bugis (Makasar), 6) suku Papua dan sebagainya, sehingga oleh budayawan dari Universitas Jember, Ayu Sutarto, Kabupaten Jember disebut sebagai daerah pandalungan.

Dari sisi bahasa yang berada di tengah-tengah masyarakat adalah bahasa berikut; 1) bahasa Jawa, 2) bahasa Madura, 3) bahasa Osing, 4) bahasa Arab, dan 5) bahasa Indonesia. Dari aspek religi atau masyarakat yang memeluk agama tertentu, penulis menyajikan data 8 kecamatan di Jember yang tingkat variasi keberagamaannya cukup tampak, sebagai bukti masyarakat multikultural. Dengan gambaran sebagai berikut:

\begin{tabular}{|l|l|l|l|l|l|l|l|}
\hline No & Kecamatan & Islam & Katolik & Protestan & Hindu & $\begin{array}{l}\text { Budh } \\
\mathrm{a}\end{array}$ & $\begin{array}{l}\text { Lain- } \\
\text { lain }\end{array}$ \\
\hline 1 & Kencong & 71.429 & 1.190 & 5.779 & 517 & 11 & 857 \\
\hline 2 & Puger & 113.550 & 370 & 486 & 54 & 9 & 397 \\
\hline 3 & Ambulu & 102.728 & 1.385 & 1.368 & 13 & 32 & 678 \\
\hline 4 & Umbulsari & 70.290 & 1.569 & 2.246 & 1.564 & - & 73 \\
\hline 5 & Semboro & 41.689 & 2.250 & 2.512 & 17 & 1 & 9 \\
\hline 6 & Kaliwates & 108.735 & 3.785 & 5.583 & 1.247 & 584 & 127 \\
\hline 7 & Sumbersari & 120.550 & 2.832 & 1.608 & 553 & 89 & 820 \\
\hline 8 & Patrang & 90.480 & 1.511 & 2.984 & 384 & 62 & 1.573 \\
\hline
\end{tabular}

(Sumber: BPS Jember tahun 2017: 133)

\footnotetext{
${ }^{4}$ Data BPS 2010. Diunduh dari laman https://nasional.kompas.com

${ }^{5}$ Data dari Badan Pengembangan dan Pembinaan Bahasa Kementerian Pendidikan dan Kebudayaan atau Badan Bahasa

${ }^{6}$ Data BPS Kabupaten Jember tahun 2016.
} 
Aspek multikulturalisme, sebagaimana diuraikan oleh Bikhu $\mathrm{Pa}$ rekh: "pengakuan perbedaan kultural, kadang-kadang bisa menyebabkan seseorang melakukan pekerjaan-pekerjaan yang tidak mampu dilakukan orang lain tanpa dukungan hak-hak keberbedaan yang secara tersirat diperlukan". ' Sebagaimana ditulis Koentjaraningrat, manusia, dengan akal dan budinya telah menciptakan dan mengembangkan berbagai macam sistem tindakan demi keperluan hidupnya, sehingga manusia menjadi mahluk yang paling berkuasa di muka bumi ini. ${ }^{8}$ Menurut Muhammad Tolchah Hasan, yang melakukan kajian terhadap pandangan Watson, Fay, Lawrence Blum, menguraikan multikulturalisme berhubungan dengan kebudayaan dan kemungkinan konsepnya dibatasi dengan muatan nilai atau memiliki kepentingan tertentu. ${ }^{9}$ dalam masalah agama, manusia paling berkuasa atau paling menonjol jika dibandingkan dengan mahluk-mahluk yang lainnya.

Emile Durkheim berpendapat bahwa seseorang sangat membutuhkan agama sebagai prinsip mendasar dan pedoman hidup dalam kehidupannya. Durkheim melihat, bahwa agama merupakan kebutuhan pokok yang selalu ada sepanjang sejarah peradaban ummat manusia. ${ }^{1} \mathrm{Hal}$ ini juga sebagaimana diuraikan oleh Zuhairi Misrawi, ia menuliskan agama merupakan suatu hal yang selalu melekat pada kehidupan ummat manusia. ${ }^{1}$

Pilihan-pilihan masyarakat dalam mengekspresikan keyakinan keberagamaannya, seringkali menimbulkan gesekan, baik di internal agamanya, lebih-lebih dengan agama lain. Hal ini tentu dapat dihindari, jika masing-

${ }^{7}$ Bikhu Parekh, Rethingking Multikulturalism; Keberagaman Budaya dan Teori Politik, Yogyakarta: Kanisius, 2008. 329

${ }^{8}$ Koentjaraningrat, Pengantar IImu Antropologi, Jakarta: PT. Rineka Cipta, 1990. 179. Zuhairi Misrawi, Al-Quran Kitab Toleransi; Tafsir Tematik Islam Rahmatan Lil Alamin, Jakarta: Oasis, 2010

9 Muhammad Tolchah Hasan, Pendidikan Multikultural; Sebagai Opsi Penanggulangan Radikalisme, Malang: Universitas Islam Malang, 2016. 7-9

1 Emile Durkheim, The Elementary Forms Of The Religious Life, Yogyakarta: Ircisod, 2011.

1 Zuhairi Misrawi, Mekkah; Koła Suci, Kekuasaan Dan Teladan Ibrahim, Jakarta: Kompas, 2009, Madinah; Kota Suci, Piagam Madinah dan Teladan Muhammad Saw Jakarta: Kompas, 2009

84 | FENOMENA, Vol.19 No.1April 2020 


\section{Leny Marinda}

masing pihak memiliki pandangan yang terbuka dan saling memahami antara satu dengan yang lainnya. ${ }^{1}$

Di Jember, sebagai setting penelitian ini, setidaknya terjadi kekerasan atas nama agama dan golongan seperti yang terjadi di Tanggul Wetan, terdapat aksi pembakaran mushala milik komunitas LDII yang dinilai sebagai kelompok yang eksklusif. ${ }^{1}$ Selain itu ada juga aksi pengrusakan terhadap pesantren Rabbani di Sumber Sari yang menurut info sebagaimana yang dilansir oleh situs republika, sering mengkritisi acara tahlilan warga sekitar. ${ }^{1}$ Ada juga konflik antara suñni-syiah di Puger yang hingga saat ini belum menemui titik penyelesaian yang pasti.

Sejumlah kasus di atas menambah daftar panjang kekerasan yang diatasnamakan agama, yang pada hakikatnya bisa diselesaikan dengan jalan dialog. Jika dicermati, kasus-kasus kekerasan mengatas namakan agama yang ada di jember ini, tidak melulu soal perbedaan pandangan terhadap ajaran keagamaan. Tetapi ada faktor salah faham yang tak berkesudahan serta like and dislike perseorangan yang kemudian di tarik sebagai konflik golongan. Untuk itu, butuh formulasi mitigasi yang tepat dalam mengurangi kekerasan-kekerasan atas nama agama dan dominasi kelompok tertentu terhadap kelompok lainnya. Pendidikan multikultural yang mengedepankan prinsip-prinsip penghargaan terhadap perbedaan menjadi salah satu opsi yang dapat dilakukan untuk meredam aksi-aksi kekerasan di atas.

Sekolah Dasar Sintha adalah salah satu sekolah dasar swasta di Jember yang memiliki siswa dengan latar belakang agama, etnis dan bahasa yang beragam. Ada penganut agama Islam, Kristen Protestan, Kristen Katolik, Hindu dan Budha yang ada di sekolah ini. Demikian pula dari segi etnis, sekolah ini memiliki siswa dari beragam etnis yaitu Jawa, Madura dan Tionghoa. Bahasa yang digunakan juga meliputi bahasa Indonesia, Inggris dan Mandarin. Oleh karena itu, peneliti merasa tertarik untuk melakukan penelitian di sekolah tersebut terkait dengan bagaimana menkondisikan multikulturalitas yang ada di dalamnya menuju efektifitas tujuan pendidi-

\footnotetext{
1 Alwi Shihab, Islam Inklusif; Menuju Sikap Terbuka Dalam Beragama, (Bandung: Mizan, 1999

${ }^{1}$ Hafid hasyim, Klaim Kebenarån Beragama, Jember: STAIN Press. 2013. 209

1 https://www.republika.co.id/Bberita/nasional/nusantaranasional/12/04/21/m2u1ut-sering-mengkritisi-tahlilan-ponpes-robbani-dirusak-warga
} 
kan. Karakteristik siswa SD yang dalam tahapan kognitif Piaget memasuki fase operasional konkrit juga menjadi tantangan tersendiri bagi guru mengolah multitulturalisme tersebut menjadi bermakna. Tujuan penelitian ini adalah untuk menjawab focus penelitian tentang bagaimana iklim pembelajaran multikultural yang ada di SD Sintha Jember; bagaimana efektifitas pelaksanaan pembelajaran dengan komposisi pendidik dan peserta didik yang beragam dan respon masyarakat (wali murid) tentang desain multikultural di SD Sintha Jember.

Setelah mengetahui tujuan penelitian dan ruang lingkup penelitian yang akan dilakukan, maka peneliti bermaksud menggunakan metode penelitian kualitatif yakni prosedur yang menghasilkan data deskriptif berupa ucapan, tulisan dan perilaku yang dapat diamati dari orang-orang di sekolah yang diteliti.

Dengan desain penelitian kualitatif ini, peneliti akan menggunakan tiga teknik pengumpulan data yakni observasi, wawancara dan dokumenter. Observasi yang akan dilakukan dengan tujuan untuk mendapatkan data tentang kondisi riil setting penelitian, gesture informan, dan iklim belajar maupun sikap peserta didik secara kasat mata. Sedangkan teknik wawancara digunakan untuk menggali informasi yang berkaitan dengan focus penelitian. Sedangkan teknik dokumenter dipakai untuk mendokumentasikan segala hal yang dilakukan penelitia selama melakukan penelitian dan hal-hal yang terkait dengan rumusan masalah yang dibahas.

Dengan metode penelitian kualitatif ini, sebenarnya peneliti tidak bisa dengan mudah menentukan informan kunci. Karena setiap individu yang ada di sekolah tersebut berpotensi menjadi informan kunci. Namun untuk memudahkan penggalian data, peneliti informan secara purposive sampling. Jadi informan yang akan di tuju adalah informan yang berkaitan dengan permasalahan yang akan diteliti, yaitu kepala sekolah, guru, siswa, orang tua siswa dan masyarakat umum sebagai informan tambahan.

Proses analisis data menggunak teknik analisis data Miles dan Huberman dengan tahapan sebagai berikut: reduksi data, display data kemudian penarikan kesimpulan. Penyajian datanya dilakukan secara naratif berupa tulisan, bagan, grafik maupun matrik.Untuk mengecek keabsahan data, peneliti menggunakan triangulasi metode. Yakni metode pemeriksaan keabsahan data dari berbagai teknik pengumpulan data yang telah dilakukan, baik itu melalui teknik wawancara, observasi maupun dokumenter.

86 | FENOMENA, Vol.19 No.1April 2020 


\section{PEMBAHASAN}

Litwin dan Stringer menjelaskan, iklim sekolah didefinisikan secara bervariasi oleh para ahli sebagai hasil dari persepsi subyektif terhadap sistem formal, gaya informal kepala sekolah, dan faktor lingkungan penting lainnya yang mempengaruhi sikap, kepercayaan, nilai dan motivasi individu yang berada pada sekolah tersebut. ${ }^{1}$

5

Wenzkaff, mengemukakan iklim suatu sekolah menginformasikan mengenai atmosfer dalam kelas, ruang fakultas, kantor dan setiap gang yang ada di sekolah. Haynes, mendefinisikan iklim sekolah sebagai kualitas dan konsistensi interaksi interpersonal dalam masyarakat sekolah yang mempengaruhi kognitif sosial pekembangan psikologi anak. Styron dan $\mathrm{Ny}-$ man menjelaskan iklim sekolah adalah komponen penting untuk mewujudkan sekolah menengah yang efektif. Iklim sekolah adalah lingkungan remaja yang ramah, santai, sopan, tenang dan enerjik. Keseluruhan iklim sekolah dapat ditingkatkan oleh sikap dan prilaku positif dari para siswa dan guru. Iklim sekolah berkaitan dengan lingkungan yang produktif dan kondusif untuk belajar siswa dengan suasana yang mengutamakan kerjasama, kepercayaan, kesediaan, keterbukaan, bangga dan komitmen. Iklim sekolah berkaitan juga prestasi akademik, moral fakultas dan prilaku siswa. Iklim sekolah menengah yang optimal adalah iklim sekolah yang resfonsif terhadap perkembangan kebutuhan setiap siswa, merangsang pertumbuhan pribadi dan akademik. Pemahaman iklim sekolah sebagai persepsi individu merujuk pada beberapa pendapat berikut. Stichter menyimpulkan iklim sekolah sebagai persepsi bersama tentang apa yang sedang terjadi secara akademis, secara sosial dan lingkungan di sekolah secara rutin. ${ }^{1}$

Namun demikian dari beberapa variasi definisi iklim sekolah tersebut apabila ditelaah lebih mendalam, maka akan mengerucut dalam tiga pengertian. Pertama, iklim sekolah didefinisikan sebagai kepribadian suatu sekolah yang membedakan dengan sekolah yang lain. Kedua, iklim sekolah didefinisikan sebagai suasana di tempat kerja yang mencakup berbagai norma

1 Gunbayi, Ilhan, School Climațe and Teacher's Perceptions on Climate Factors : Research Into Nine Urban High Schools, The Turkish Online Journal of Educational Technology (TOJET), 2007. 1

1 Stichter, Kenneth, Student School Climate Perceptions as a Measure of School District Goal Attainment, Journal of Educational Research \& Policy Studies, 2008. 45

FENOMENA, Vol.19 No.1April 2020 | 87 
yang kompleks, nilai, harapan, kebijakan dan prosedur yang mempengaruhi pola prilaku individu dan kelompok. Ketiga, iklim sekolah didefinisikan sebagai persepsi individu terhadap kegiatan, praktik dan prosedur serta persepsi tentang prilaku yang dihargai, didukung dan diharapkan dalam suatu organisasi. Pemahaman iklim sekolah sebagai suatu kepribadian suatu sekolah merujuk kepada beberapa pendapat berikut. Halpin dan Croft menjelaskan bahwa iklim sekolah sebagai suatu intangible tetapi penting untuk sebuah organisasi dan dianalogikan dengan kepribadian seorang individu. ${ }^{1}$

Iklim secara luas menggambarkan persepsi bersama menyangkut beberapa hal yang ada di sekeliling kita. Secara sempit iklim diartikan sebagai persepsi bersama mengenai kebijakan organisasi dan prosedur pelaksana, baik secara formal maupun informal. Berdasarkan beberapa pendapat para ahli di atas, maka dapat dinyatakan bahwa iklim sekolah adalah suasana yang diciptakan oleh kepala sekolah selaku pemimpin yang dapat menunjang terjadinya proses belajar mengajar.

Secara sederhana, 'multikultural' dapat berarti 'keragaman budaya'. Istilah multikultural dibentuk dari kata 'multi' yang berarti plural; banyak; atau beragam, dan 'kultur' yang berarti budaya. Kultur atau budaya merupakan ciri-ciri dari tingkah laku manusia yang dipelajari, tidak diturunkan secara genetis dan bersifat khusus, sehingga kultur pada masyarakat tertentu bisa berbeda dengan kultur masyarakat lainnya. Dengan kata lain, kultur merupakan sifat yang "khas" bagi setiap individu (person) atau suatu kelompok (comunitee) yang sangat mungkin untuk berbeda antara satu dengan yang lainnya. Semakin banyak komunitas yang muncul, maka semakin beragam pula masing-masing kultur yang akan dibawa.

Menurut Bikhu Parekh, ${ }^{1}$ diskursus tentang multikufturalisme mencakup dalam tiga wilayah sebagai berikut: Pertama, kelompok masyarakat yang memiliki sistem nilai dan praktek-praktek tradisi yang berbeda dengan masyarakat pada umumnya. Mereka hidup di tengah masyarakat umum dan tradisi dominan, tetapi sekaligus hendak menciptakan ruang bagi tradisi yang mereka yakini dan sistem nilai yang dianut. Mereka tidak hendak mendesakkan tradisi dan sistem nilai yang dianut, tetapi menghendaki adanya penghar-

1 Tubbs, JE, dan Garner, M, The Impact of School Climate on School Outcomes, Journal Of College Teaching and Learning, 2008. 17

1 Bikhu Parekh, Rethingking Ml'sultikulturalism; Keberagaman Budaya dan Teori Politik,, Yogyakarta: Kanisius.2008

88 | FENOMENA, Vol.19 No.1April 2020 


\section{Leny Marinda}

gaan dan pemberian ruang untuk mengekspresikan tradisi dan sistem nilai yang dianut. Kelompok ini misalnya : kelompok gay, lesbian, single parent, dan anak jalanan. Kelompok masyarakat seperti itu oleh Bhiku Parekh, disebut dengan subculture diversity.

Kedua, kelompok masyarakat yang kritis dengan budaya dominan (utama) dan berusaha untuk merebut serta merubah dan membentuk kembali seperti cara pandang yang mereka inginkan. Kelompok ini misalnya: kaum feminis (kritis-radikal), aktivis lingkungan radikal, kaum fundamentalisradikal agama yang menolak sekularisasi dan sekularisme, aktivis pendidikan alternatif-partisipatoris. Kelompok masyarakat ini disebut dengan perspective diversity.

Ketiga, kelompok masyarakat yang memiliki sistem nilai sebagai cara pandang dan praktek hidupnya sendiri. Mereka ini terorganisir dengan baik dalam masyarakatnya. Misalnya masyarakat pendatang/imigran, kelompok agama suku, suku-suku asli, kelompok masyarakat di daerah-daerah (teritori) tertentu seperti suku Badui, Samin, dan seterusnya. Mereka disebut dengan communal diversity.

Pendidikan, dalam kamus besar bahasa Indonesia adalah sebuah sebuah pengubahan sikap dan tata laku seseorang atau kelompok orang dalam usaha mendewasakan manusia melalui upaya pengajaran dan pelatihan. Di dalam undang-undang sistem pendidikan nasional telah dijelaskan bahwa, pendidikan adalah usaha sadar dan terencana dalam mewujudkan suasana belajar dan proses pembelajaran agar peserta didik secara aktif mengembangkan potensi diri, kepribadian, kecerdasan, akhlak mulia, serta keterampilan yang diperlukan dirinya, masyarakat, bangsa, dan Negara. ${ }^{1}$

Berdasarkan pengertian di atas, dapat kita simpulkan bahwa yang dimaksud pendidikan adalah usaha sadar seseorang atau kelompok masyarakat dalam mengembangkan potensi yang ada pada dirinya untuk kemaslahatan diri, sosial, bangsa dan negranya. Dengan demikian, melalui pendidikan, seseorang bisa mengembangkan kesadaran multikultural yang ada di lingkungan sekitarnya.

Azzumardy Azra mendefinisikan pendidikan multikultural sebagai pendidikan utuh tentang keberagaman kebudayaan dalam merepon perubahan demografis dan kultural lingkungan masyarakat tertentu atau berlaku

1 Undang-Undang Sistem Peñdidikan Nasional (SISDIKNAS) Nomor 20 Tahun 2003, Bandung: Nuansa Aulia

FENOMENA, Vol.19 No.1April 2020 | 89 
secara keseluruhan. Pendidikan multikultural berusaha memberdayakan seluruh komponen warga sekolah untuk mengembangkan rasa hormat kepada orang yang berbeda budaya. ${ }^{2}$

Sebagaimana telah disebutkan oleh Kiai Tolhah Hasan, ${ }^{2}$ Maskuri, ${ }^{2}$ Muhammad Imarah, Sirry (dkk), dan Moqsith Ghozali di atas, ternyata bumi dimana kita diam, bumi dimana kita hidup, bumi dimana kita beribadah, bumi dimana kita belajar hari ini, merupakan kawasan wilayah yang termasuk dibahas dalam tulisan ini. Lebih lanjut Maskuri menguraikan tentang apa dan bagaimana Indonesia yang besar ini.

Dalam kajian Maskuri yang juga mengutip pembahasan Rindjin dan Putrayasa, keanekaragaman Indonesia dapat diuraikan sebagai berikut, Indonesia memiliki 13.487 pulau, (6.004 dihuni manusia), 746 bahasa daerah, 556 suku bangsa, dan 19 hukum adat, dengan 6 agama dan beberapa aliran kepercayaan, demikian juga seni budaya daerah yang cukup beragam. 2

Dalam kajian Kiai Tolchah Hasan, ia setuju dengan pemikir yang mengatakan bahwa Indonesia terdiri dari, 13.000 pulau, dengan 250 juta jiwa penduduk, dengan sekitar 300 suku, dengan sekitar kurang lebih 200 bahasa daerah, dengan 6 agama resmi yang diakui Negara. Dengan jumlah umat Islam 207 juta atau 87,2 \%, Protestan 16,5 juta atau $7 \%$, Katolik sebanyak 7 juta atau $3 \%$, Hindu 4 juta atau 1,7 \%, Budha 1,7 atau 0,7 \% dan yang lainlainnya mencapai 1,3 juta atau $0,5 \%{ }^{2}$

Menurut Radhar Panca Dahana, Indonesia dengan 17.000 pulau lebih, dengan sekitar 600 bahasa, dan 350 etnik, merupakan salah satu negara multikultural sepanjang sejarah peradaban umat manusia, orang Indonesia mampu hidup berdampingan secara rukun dan damai hingga beribu-ribu tahun, mulai abad 7-9 (Kerajaan Sriwijaya), 13-15 (Kerajaan Majapahit) hingga sekarang abad 21, (menjadi Negara Indonesia). ${ }^{2}$

2 Azzumardi Azra, Pendidikah Multikultural (Membangun Kembali Indonesia Bhineka Tunggal Ika)

2 Maskuri, dkk, Kyai Tanpa Pesantren; Kiprah Dan Pengabdian Sang Kyai Dalam Pandangan Para Akademisi, Malang: Paramasastra Press, 2007.

2 Maskuri Bakri, Kebijakan P’endidikan Islam, pada bab 4 tentang Kebijakan Pendidikan Islam Tentang Multikultural, Jakarta: Nirmana Media, 2013. 129-130.

2 Muhammad Tolchah Håsan, Pendidikan Multikultural Sebagai Opsi Penanggulangan Radikalisme, Malang: Unisma, 2016.141

2 Radhar Panca Dahana, Menjādi Manusia Indonesia, Yogyakarta: LKIS, 2001. 65.

90 | FENOMENA, Vol.19 No.1April 2020 


\section{Leny Marinda}

Sebagaimana diuraikan oleh Maskuri, Indonesia memiliki aturan yang dapat menjadi pijakan pelaksanaan pendidikan multikultural di Indonesia. Misalkan dari UUD 1945 pada Bab 13, pasal 31 (ayat 1 dan 5), pasal 32 (ayat 1 dan 2), juga dalam Undang-Undang Nomor 20 tahun 2003 tentang sistem pendidikan nasional, Bab I (pasal 1 ayat 2), Bab 4 Bagian Keempat (pasal 11 ayat 1), serta Peraturan Pemerintah Nomor 17 tahun 2010 (tentang pengelolaan dan penyelenggaraan pendidikan), Keputusan Menteri Agama Republik Indonesia Nomor 211 tahun 2011 (tentang Pedoman Pengembangan Standar Nasional Pendidikan Agama Islam Pada Sekolah), dan UndangUndang Nomor 32 tahun 2004 (revisi UU No 22 tahun 1999) tentang Pemerintahan Daerah. ${ }^{2}$

Benyamin molan mengutip Bdk Kasdin Sihotang menggaris bawahi esensi pendidikan multikultural adalah pengakuan dan penghargaan terhadap perbedaan. ${ }^{2}$ pendidikan ini bergerak untuk memahami, menerima keanekaragaman sebagai bagian eksistensi manusia. Model ini membuka indera kaum muda bahwa perbedaan merupakan bagian dari dirinya.

Di sini terjadi konstientisasi untuk senantiasa menerima dan mengakui hak orang lain serta tidak sungkan memberi ruang lebih luas kepada mereka untuk mengungkapkan hakikat kemanusiaan yang multidimensional. Bagi kaum muda kesadaran ini merupakan dasar untuk mampu melihat, mengenal, memiliki kematangan bernalar secara sehat dalam realitas sosial.

Konsep pendidikan multikultural memuat 4 seruan yaitu: (1) pendidikan seyogyanya mengembangkan kesadaran untuk memahami dan menerima sistem nilai dan kebhinekaa pribadi, jenis kelamin, ras, etnik dan kultur, (2) mendorong konvergensi gagasan yang memperkokoh perdamaian, persaudaraan dan solidaritas dalam masyarakat, (3) membangun kesadaran untuk menyelesaikan konflik secara damai, (4) pendidikan seyogyanya meningkatkan pengembangan kualitas toleransi dan kemauan berbagi secara mendalam.

Pendidikan multikultural memberikan kebermanfaatan untuk membangun kohesivitas, solidaritas dan intimitas antar etnik, ras, agama dan bu-

2 Maskuri Bakri, Kebijakan Pendidikan Islam, pada bab 4 tentang Kebijakan Pendidikan Islam Tentang Multikultural, Jakarta: Nirmana Media, 2013. 140.

2 Benyamin Molan, Multikulturalisme: Cerdas Membangun Hidup Bersama Yang Stabil Dan Dinamis, Jakarta: Indeks, 2015. Xi. Baca juga Bikhu Parekh, Rethinking Multikulturalism, Yogyakarta: Kanisius, 2008

FENOMENA, Vol.19 No.1April 2020 | 91 
daya telah memberi dorongan kepada lembaga pendidikan untuk study menanamkan kesadaran kepada peserta didik untuk menghargai orang, budaya, dan agama. ${ }^{2}$

Secara garis besar muara dari pendidikan multikultural adalah sikap demokratis, sikap pluralis dan sikap humanis. ${ }^{2}$ Ketiga sikap inilah yang ${ }^{9}$ menjadi lokus kajian dalam penelitian ini. sikap pluraris ${ }^{3}$ membangun paradigma keberagaman inklusif, ${ }^{3}$ menghargai keragaman bahasa, menghargai perbedaan umur, menghargai perbedaan pendapat dan belajar hidup dalam perbedaan. sikap pluralis juga mengarah kepada rasa menerima dan menghargai suatu perbedaan yang ada di tengah masyarakat. Sedangkan yang dimaksut dengan sikap demokratis adalah membangun sikap anti diskriminasi terhadap etnik, menghargai perbedaan kemampuan, membangun sikap saling pengertian, menjunjung sikap saling menghargai dan saling percaya antar kelompok dalam masyarakat. Dan yang menjadi ruang lingkup sikap humanis $^{3}$ adalah membangun sensitiffitas gender dan membangun pemahaman kritis terhadap ketidakadilan dan perbedaan status sosial.

SD Sintha merupakan salah satu sekolah dasar yang beralamatkan di Jl. KH. Shiddiq no. 113 kelurahan Jember Kidul kecamatan Kaliwates kabupaten Jember. Sekolah dasar ini merupakan sekolah dasar swasta di bawah yayasan. Sekolah dengan akreditasi A yang menjadi setting lokasi penelitian ini merupakan salah satu sekolah dasar yang menerima dan mengakomodir siswa dari berbagai etnis, agama, seperti Islam, Kristen, katolik, Hindu dan budha. sejak berdirinya di tahun 2013, sekolah ini juga telah menerima dengan latar belakang suku dan ras yang beragam seperti suku Jawa, Madura dan ras Tionghoa. Sehingga pelajaran bahasa yang ada di sini meliputi bahasa Indonesia, jawa, mandarin dan inggris.

2 Noor Sulistyabudi, Bambång Suta, Salamun, Implementasi Pendidikan Multikultural Di Sma Daerah Istimewa Yogyakarta, Yogyakarta: BNPB DIY Yogyakarta, 2014. 7

2 Abdul Muis Tabrani, Pengaintar Dan Dimensi-Dimensi Pendidikan, Jember: STAIN Jember Press, 2013. 135

3 sebagai bahan pengayaan Teferensi lihat Abd. Moqsith Ghazali, Argument Pluralism Agama, Jakarta: Katakita, 2009,

3 baca Alwi Sihab, Islam Inklusif, Bandung: Mizan, 1999

3 lihat dalam Nur Syam, Tan'tangan Multikulturalisme Indonesia, Yogyakarta: Kanisius, 2009

92 | FENOMENA, Vol.19 No.1April 2020 


\section{Leny Marinda}

Sebagaimana yang disampaikan oleh Ibu Yanti, kepala sekolah SD Sintha Jember, memaparkan bahwa di SD Sintha baik guru maupun siswa memperoleh kesempatan dan kelonggaran dalam menjalankan peribadatan sesuai dengan agama yang dianutnya. Tidak ada pelarangan dan pembatasan dari yayasan sebagai pengampu kebijakan di SD tersebut. oleh sebab itu, di SD Sintha, setiap hari besar keagamaan seperti hari raya Idul Fitri, Idul Adha, Tahun Baru Islam (1 Hijriah), kebaktian paskah, Natal, Imlek, semuanya mendapatkan kesempatan yang sama untuk dirayakan. Dalam pelaksanaannyapun mereka saling membatu dan "tahu diri". Ketika dilaksanakan kegiatan keagmaan Islam seperti pondok Ramadhan, Tahun baru Islam, Idul Adha maka siswa yang beragama non muslim akan membantu dengan menyiapkan sarana dan konsumsi agar peribadatan berjalan dengan khidmat. Begitu pula sebaliknya, ketika siswa yang non muslim sedang mendapatkan kesempatan untuk melakukan ritual peribadatan, maka siswa muslim yang membantu. Hal ini dikarenakan guru dan siswa yang ada di SD Sintha berasal dari latar belakang agama dan etnis yang majemuk sebagaimana yang dipaparkan di atas. $^{3}$ 3

Hal diatas merupakan salah satu alasan yang dikemukanan oleh salah seorang wali murid bernama Dyah Astari, untuk menitipkan putrinya ke SD tersebut. menurutnya, dengan membiasakan anak untuk berkumpul dan bersosialisasi dengan orang-orang yang berbeda, akan mudah menumbuhkan sikap menghargai terhadap perbedaan itu sendiri. ${ }^{3}$ sehingga anak mudah bergaul dan tidak terbiasa membeda-bendakan dalam berteman. ${ }^{3}$

Selain itu, untuk memfasilitasi pembelajaran agama yang beraneka ragam, sekolah menyediakan ruangan khusus bagi setiap penganut agama. hal ini disampaikan oleh Ibu Ajeng, salah satu guru di SD Sintha, bahwa ketika pembelajaran agama berlangsung, siswa-siswa secara otomatis akan berpindah kelas dan masuk ke ruangan agama sesuai agama yang dianut mereka. Ruang kelas dipakai oleh siswa Kristen, karena jumlahnya lebih banyak. Untuk siswa yang beragama selainnya disediakan ruangan khusus tiaptiap agama dengan guru yang sesuai bidang yang siap membimbing dan

3 Wawancara dengan Dra. KM³. Darjanti, kepala sekolah SD Sintha Jember, pada 23 Juli 2019

3 Wawancara dengan Dyah Astari, wali murid SD Sintha Jember

3 Observasi dan wawancara te thadap Vanesa. Siswi kelas VI SD Sintha Jember

FENOMENA, Vol.19 No.1April 2020 | 93 
memberikan pelajaran agama. ${ }^{3}$ Kecuali untuk siswa yang Beragama Hindu. Karena jumlah siswa yang beragama Hindu yang hanya 5 orang, maka sekolah mengambil kebijakan untuk menyerahkan bimbingan agama untuk siswa beragama Hindu kepada Pura masing-masing. Untuk melihat komposisi siswa SD Sintha menurut agama yang dianut adalah sebagai berikut:

Table 1. pemetaan siswa menurut agama tahun pelajaran 2018/2019

\begin{tabular}{|c|c|c|c|c|c|c|c|}
\hline Agama & $\begin{array}{c}\text { Kelas } \\
\text { I }\end{array}$ & $\begin{array}{c}\text { Kelas } \\
\text { II }\end{array}$ & $\begin{array}{c}\text { Kelas } \\
\text { III }\end{array}$ & $\begin{array}{c}\text { Kelas } \\
\text { IV }\end{array}$ & $\begin{array}{c}\text { Kelas } \\
\text { V }\end{array}$ & $\begin{array}{c}\text { Kelas } \\
\text { VI }\end{array}$ & Jumlah \\
\hline Islam & 8 & 5 & 3 & 2 & 5 & 3 & 26 \\
\hline Kristen & 4 & 6 & 6 & 9 & 16 & 7 & 48 \\
\hline Katolik & 3 & & 1 & 4 & 3 & 6 & 17 \\
\hline Hindu & 1 & & 1 & 1 & 1 & 1 & 5 \\
\hline Budha & & & & & & & \\
\hline Jumlah & 16 & 11 & 11 & 16 & 25 & 17 & 96 \\
\hline
\end{tabular}

Jember sebagai daerah pandalungan yang terdiri dari masyarakat suku Jawa dan Madura, ternyata memiliki implikasi nyata terhadap komposisi guru dan siswa SD Sintha dilihat dari etnisnya. SD Sintha ini didirikan oleh yayasan yang $40-50 \%$ anggotanya adalah warga etnis Tionghoa. Namun, prosentase ini tidak berbanding lurus dengan prosentas siswa dilihat dari kewarganegaraannya. Karena nyatanya, siswa yang sekolah di lembaga ini banyak berasal dari non-Tionghoa, dengan kata lain siswa dari suku Jawa dan Madura. Berikut pemetaan jumlah siswa dilihat dari kewarganegaraannya.

Table 2. pemetaan siswa berdasarkan kewarganegaraan tahun pelajaran $2018 / 2019$

\begin{tabular}{|l|c|c|c|c|c|c|c|}
\hline $\begin{array}{c}\text { Kewarga- } \\
\text { negaraan }\end{array}$ & $\begin{array}{c}\text { Kelas } \\
\text { I }\end{array}$ & $\begin{array}{c}\text { Kelas } \\
\text { II }\end{array}$ & $\begin{array}{c}\text { Kelas } \\
\text { III }\end{array}$ & $\begin{array}{c}\text { Kelas } \\
\text { IV }\end{array}$ & $\begin{array}{c}\text { Kelas } \\
\text { V }\end{array}$ & $\begin{array}{c}\text { Kelas } \\
\text { VI }\end{array}$ & Jml \\
\hline WNI Asli & 14 & 10 & 5 & 13 & 16 & 11 & 69 \\
\hline $\begin{array}{l}\text { WNI } \\
\text { ket.Tiongho } \\
\text { a }\end{array}$ & 2 & 1 & 6 & 3 & 9 & 6 & 27 \\
\hline $\begin{array}{l}\text { WNI Ket. } \\
\text { Arab }\end{array}$ & & & & & & & \\
\hline $\begin{array}{l}\text { WNI. Ket } \\
\text { lainnya }\end{array}$ & & & & & & & \\
\hline
\end{tabular}

3 Wawancara dengan Sri Rahaøyu Wilujeng, wali kelas III pada 23 Juli 2019

94 | FENOMENA, Vol.19 No.1April 2020 


\section{Leny Marinda}

\begin{tabular}{|l|c|c|c|c|c|c|c|}
\hline Jumlah & 16 & 11 & 11 & 16 & 25 & 17 & 96 \\
\hline
\end{tabular}

Setiap harinya, 10 menit sebelum masuk kelas, siswa akan berkumpul bersama untuk menerima pelajaran budi pekerti (apel budi pekerti). Dalam pelajaran budi pekerti ini, anak diajak untuk menghormati antara satu dengan lainnya, tidak saling mengejek dan merendahkan, mendeskreditkan yang minoritas. ${ }^{3}$ Hal ini penting untuk disarnpaikan untuk menanamkan rasa saling menghargai sejak dini, mengingat desain sekolah tersebut yang menerima siswa dengan berbagai latar belakang agama dan etnis. Pernah kejadian guru muslim memosting di whatsapp grup tentang materi pelarangan memberikan ucapan selamat natal kepada umat nasrani. Untuk menghindari perasaan tidak nyaman kepada guru nasrani, yayasan memanggil guru muslim tersebut dan menasehati untuk tidak lagi mengirimkan pesan berantai dengan konten yang mengarah terhadap pendeskreditan terhadap salah satu agama atau etnis. Kalaupun diyakini itu benar, cukuplah menjadi konsumsi pribadi dan atau komunitas yang segolongan. Supaya tidak mengganggu mereka yang kebetulan "berbeda" pandangan dan keyakinan. ${ }^{3}$

Untuk mengakomodir pelestarian budaya bawaan siswa, maka Pelajaran bahasa yang masuk dalam kurikulum di sekolah ini adalah Bahasa Indonesia (wajib), bahasa inggris, bahasa mandarin dan bahasa jawa sebagai muatan lokalnya. Sehingga masing-masing siswa dapat saling mempelajari bahasa-bahasa temannya dan memperkaya khasanah kebahasaan mereka.

Dari temuan penelitian di atas, yang terjadi di SD Sintha, menurut merupakan desain pembelajaran yang kontributif mengingat kondisi Indonesia saat ini yang rentan terjangkit ketegangan mengatasnamakan agama dan kelompok etnis tertentu. Dengan pembiasaan dan pemahaman yang komprehensif tentang perbedaan, maka siswa secara dini telah diajak untuk menjalani miniatur kemajemukan Indonesia dengan bergaul bersama teman yang "berbeda" dengan mereka tanpa melepaskan identitas keagamaan dan kebudayaan yang melekat di tiap-tiap individu.

SD Sintha juga memberikan potret bagaimana pembelajaran multikultural yang berlangsung bermuara pada empat konsep pendidikan multikultural: (1) pendidikan seyogyanya mengembangkan kesadaran untuk memahami dan menerima sistem nilai dan kebhinekaa pribadi, jenis kelamin,

\footnotetext{
3 Observasi pada hari sabtu $20^{7}$ Juli 2019

3 Wawancara dengan Dra. KM․ Darjanti, kepala sekolah SD Sintha Jember, pada 23 Juli 2019
}

FENOMENA, Vol.19 No.1April 2020 | 95 
ras, etnik dan kultur, (2) mendorong konvergensi gagasan yang memperkokoh perdamaian, persaudaraan dan solidaritas dalam masyarakat, (3) membangun kesadaran untuk menyelesaikan konflik secara damai, (4) pendidikan seyogyanya meningkatkan pengembangan kualitas toleransi dan kemauan berbagi secara mendalam. Temuan penelitian ini mengemukakan bahwa SD Sintha melaksanakan konsep pendidikan multikultural di atas dalam mengelola kemajemukan yang dimilikinya.

\section{KESIMPULAN}

Berdasarkan temuan dan diskusi penelitian di atas, maka ada beberapa hal yang dapat ditarik sebagai benang merah kajian. Yaitu: 1) SD Sintha Jember merupakan lembaga pendidikan yang mampu menerapkan prinsipprinsip pembelajaran multikultural; 2) Desain pendidikan yang ada di SD Sintha dapat dijadikan referensi yang kontributif dalam menekan egoisme dan sentimen keagamaan, karena menampilkan perbedaan dalam kedamian sejak dini.

Hal-hal yang dapat dijadikan rekomendasi berdasarkan penelitian ini adalah: 1) Dengan memperhatikan perkembangan siswa tingkat SD yang merupakan fase operasional konkrit, maka internalisasi kesadaran multikultural penting untuk semakin dikuatkan. Multikultural tidak hanya berkutat di wilayah agama, budaya, bahasa dan etnis saja, tetapi juga kebiasaan-kebiasaan antar kelompok yang berbeda juga penting untuk diberi ruang sepanjang tidak bertentangan dengan norma agama, sosial, dan hukum yang berlaku; dan 2) Memberikan wawasan penghargaan dan etika tentang bagaimana mayoritas bersikap terhadap minoritas, serta minoritas terhadap mayoritas. Hal ini

untuk menghindari bentuk-bentuk subordinasi terhadap pemeluk agama lain dengan mengatas namakan ajaran agama.

\section{DAFTAR RUJUKAN}

Suaedi, Ahmad dkk, 2007, Politisasi Agama Dan Konflik Komunal: Beberapa Isu Penting Di Indonesia, Jakarta: The Wahid Institute

Abd. Muis, Abd, 2013, Pengantar Dan Dimensi-Dimensi Pendidikan, Jember: STAIN Press

BPS 2010. Diunduh dari laman https://nasional.kompas.com

Badan Pengembangan dan Pembinaan Bahasa Kementerian Pendidikan dan Kebudayaan atau Badan Bahasa

96 | FENOMENA, Vol.19 No.1 April 2020 


\section{Leny Marinda}

BPS Kabupaten Jember tahun 2016.

Parekh, Bikhu, 2008, Rethingking Multiculturalism; Keberagaman Budaya dan Teori Politik, Yogyakarta: Kanisius

Koentjaraningrat, 1990, Pengantar Ilmu Antropologi, Jakarta: PT. Rineka Cipta

Misrawi, zuhairi, 2010, Al-Quran Kitab Toleransi; Tafsir Tematik Islam Rabmatan Lil Alamin, Jakarta: Oasis, 2010

Hasan, Muhammad Tolchah , 2016, Pendidikan Multikultural; Sebagai Opsi Penanggulangan Radikalisme, Malang: Universitas Islam Malang

Durkheim, Emile , 2011, The Elementary Forms Of The Religious Life, Yogyakarta: Ircisod

Misrawi, Zuhairi, 2009, Mekekah; Kota Suci, Kekuasaan Dan Teladan Ibrabim, Jakarta: Kompas, 2009, Madinah; Kota Suci, Piagam Madinah dan Teladan Muhammad Saw Jakarta: Kompas, 2009

Alwi Shihab, Alwi, 1999, Islam Inklusif; Menuju Sikap Terbuka Dalam Beragama, (Bandung: Mizan, 1999

Hafid Hasyim, Hafid, 2013, Klaim Kebenaran Beragama, Jember: STAIN Press. 2013. 209

https://www.republika.co.id/berita/nasional/nusantaranasional $/ 12 / 04 / 21 / \mathrm{m} 2 \mathrm{u} 1$ ut-sering-mengkritisi-tahlilan-ponpesrobbani-dirusak-warga

Undang-Undang Sistem Pendidikan Nasional (SISDIKNAS) Nomor 20 Tahun 2003, Bandung: Nuansa Aulia

Azra, Azzumardi, Pendidikan Multikultural Membangun Kembali Indonesia Bhineka Tunggal Ika)

Molan, Benyamin, 2015, Multikulturalisme: Cerdas Membangun Hidup Bersama Yang Stabil Dan Dinamis, Jakarta: Indeks

Sulistyabudi, Noor, 2014, Bambang Suta, Salamun, Implementasi Pendidikan Multikultural Di Sma Daerah Istimewa Yogyakarta, Yogyakarta: BNPB DIY Yogyakarta,

Ghazali, Abd. Moqsith , 2009, Argument Pluralism Agama, Jakarta: Katakita Syam, Nur, 2009, Tantangan Multikulturalisme Indonesia, Yogyakarta: Kanisius

Gunbayi, Ilhan, School Climate and Teacher`s Perceptions on Climate Factors : Research Into Nine Urban High Schools, The Turkish Online Journal of Educational Technology (TOJET), 2007

Tubbs, JE, dan Garner, M, 2008, The Impact of School Climate on School Outcomes, Journal Of College Teaching and Learning 
Stichter, Kenneth, Student School Climate Perceptions as a Measure of School District Goal Attainment, Journal of Educational Research \& Policy Studies, 2008. 45

Maskuri, dkk, 2007, Kyai Tanpa Pesantren; Kiprah Dan Pengabdian Sang Kyai Dalam Pandangan Para Akademisi, Malang: Paramasastra Press

Maskuri Bakri, 2013, Kebijakan Pendidikan Islam, pada bab 4 tentang Kebijakan Pendidikan Islam Tentang Multikultural, Jakarta: Nirmana Media

Dahana, Radhar Panca , 2001, Menjadi Manusia Indonesia, Yogyakarta: LKIS. 